\section{Kovalov 5., Parsadanov I., Plis 5.}

\title{
DEVELOPMENT AND RESEARCH THE ELECTRONIC CONTROL SYSTEM FOR GAS ENGINES CONVERTED ON THE BASIS OF DIESELS
}

The object of research is an electronic microprocessor control system for gas internal combustion engines with spark ignition for operation on liquefied petroleum gas. The system consists of two main subsystems, the accumulative power supply common rail LPG injection subsystem and the contactless electronic ignition subsystem with a movable voltage distributor. In addition, the control system also includes a subsystem for controlling the filling of the cylinders with the charge of the working mixture, consisting of a throttle valve and an idle speed regulator with a conical damper. The control system, depending on the software version, is capable of providing group or sequential injection of liquefied petroleum gas into the inlet pipe of each cylinder in the area close to the inlet valve. Such a control system can be used when converting (re-equipping) both new diesel engines into spark-ignition gas engines, and those that are in operation. The feasibility of such a conversion is to reduce operating costs with powerful vehicles for diesel fuel, by replacing it with cheaper and environmentally friendly liquefied petroleum gas.

To test the efficiency of the control system, a D-240-LPG-«B» model gas engine was developed and manufactured to operate on liquefied petroleum gas. The gas engine was converted on the basis of the D-240 transport diesel engine (atmospheric, four-stroke, liquid-cooled, 4-cylinder engine with a piston diameter of $110 \mathrm{~mm}$ and a stroke of $125 \mathrm{~mm}$ ). Reducing the compression ratio of the diesel engine was achieved by modifying a semi-closed diesel combustion chamber of the TSNIDI type into an open combustion chamber in the form of an axisymmetric «truncated cone». For efficient control of three subsystems of the D-240-LPG-«B» model gas engine, an electronic microprocessor control unit of the Avenir Gaz $37 \ll B »$ model was developed and manufactured. The tests carried out on the D-240-LPG-«B» gas engine with the Avenir Gaz $37 \ll B »$ control unit showed the efficiency of using the electronic microprocessor control system.

Keywords: gas engine, gas engine control system, electronic control unit, liquefied petroleum gas.

Received date: 08.05.2020

Accepted date: 13.06 .2020

Published date: 31.10 .2020
Copyright (c) 2020, Kovalov S., Parsadanov I., Plis S. This is an open access article under the CC BY license (http://creativecommons.org/licenses/by/4.0)

\section{Introduction}

Many researchers and enterprises both in the world and in Ukraine [1-3] are engaged in the conversion of transport diesel engines into internal combustion engines (hereinafter - ICE) with spark ignition for operation on gas motor fuels.

At the same time, the main feature of these transitions is the choice of a method for reducing the compression ratio of diesel engines. These include the three most wellknown methods. The first is the installation of additional cylinder head gaskets [1, 3], which leads to a significant deterioration in the environmental parameters of a convertible gas ICE. The second is the use of Miller thermodynamic cycle, which provides a decrease not in the geometric, but in the actual compression ratio [4, 5]. But it should be noted that the use of the Miller cycle, in which the diesel form of the combustion chamber remains unchanged, does not solve the main problem of ensuring the energy efficient and ecological operation of the gas ICE. But the most common third method is to reduce the actual compression ratio, which is provided by increasing the volume of the combustion chamber [6-8]. Methods for increasing the volume of the combustion chamber for various forms of combustion chambers are analyzed in detail in [9].

The second main difference between these transitions is the use of one of the two most common types of gas motor fuels - compressed natural gas (hereinafter referred to as $\mathrm{CNG}$ ) or liquefied petroleum gas (hereinafter referred to as LPG). It should be noted that in most of the work on converting transport diesel engines into gas ICE, CNG was used as a motor fuel. But the disadvantage of using $\mathrm{CNG}$ as a motor fuel for vehicles is the need to establish a significant number of sufficiently heavy automobile gas cylinders. This, in turn, requires a decrease in either the passenger capacity or the carrying capacity of the vehicle. In contrast to CNG, the use of LPG, due to its volumetric energy density, which is close to gasoline and diesel fuel, does not require such a change.

In addition, it is known that the LPG consumption by vehicles in the world in recent years has increased significantly, while their number has exceeded 25 million [10].

So, the object of research is an electronic microprocessor control system for gas ICEs with spark ignition for LPG operation. The aim of research is to develop and research an electronic microprocessor control system for a gas ICE with an electronic control unit (hereinafter 
referred to as ECU) Avenir Gaz $37 \ll \mathrm{B} »$, which provides group or sequential LPG injection.

\section{Methods of research}

The study used:

- non-motorized tests of the electronic control unit Avenir Gaz 37 «B» on a specially created modeling stand; - bench (motor) tests of an electronic microprocessor control system for a gas ICE with an Avenir Gaz 37 «B» electronic control unit as part of a D-240-LPG- $\ll$ B» gas engine.

To carry out the commissioning of the Avenir Gaz 37 «» ECU, a special modeling stand was developed and manufactured. The stand consisted of input sensors and devices, as well as executive elements and devices that are part of an electronic microprocessor control system for a 4-cylinder gas ICE. The input of the stand sensors includes:

- speed sensor and the angular position of the crankshaft and the Hall sensor of the distributor (signals from which were simulated by pulse generators);

- sensor of the angular position of the throttle valve; - coolant temperature sensor.

The executive elements and stand devices include:

- Common Rail gas rail with four low-resistance electromagnetic gas injectors;

- three solenoid valves (which are part of the reducerevaporator, the multivalve of the gas cylinder and the LPG filter valve);

- idle speed regulator.

All elements of special equipment included in the power supply system and group or sequential LPG injection meet the requirements [11, 12].

The compression ratio of the D-240 diesel engine $(\varepsilon=6)$ was reduced in the third way. Thus, a semi-closed diesel combustion chamber of the TsNIDI type was transformed into an open combustion chamber in the form of a axisymmetric «truncated cone» with $\varepsilon=9.5$ [9].

Bench tests of an electronic microprocessor control system for a gas ICE model D-240-LPG-«B» with an Avenir Gaz 37 «» ECU were carried out on a Zöllner (Germany) electric load stand of the B-350AS type (Fig. 1).

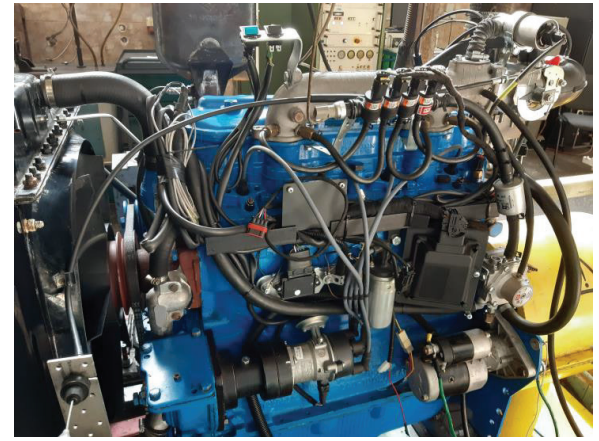

$a$

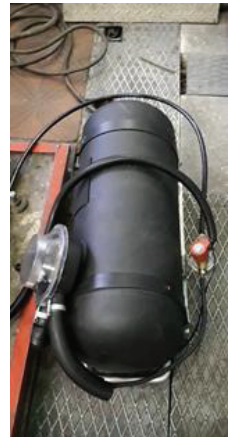

$b$
Fig. 1. Photo of a gas internal combustion engine (ICE) D-240-LPG-«B» installed on a Zöllner electric load stand of the B-350A5 type: $a$ - gas ICE at the stand; $b$ - gas cylinder for supplying a gas ICE with liquefied petroleum gas

The stand is equipped with a modernized microprocessor-based measurement and control system. The system measures, calculates and stores all parameters of a gas-fired ICE necessary for bench tests, and also records environmental parameters in the test box.

\section{Research results and discussion}

A multifunctional microprocessor-based ECU Avenir Gaz 37 «B was developed and manufactured to control the gas engine operation (Fig. 2). The engine was equipped with three subsystems:

- accumulative power supply subsystem and multipoint injection by LPG electromagnetic gas nozzles;

- contactless electronic ignition subsystem (hereinafter

- CEIS) with a movable voltage distributor;

- subsystem for controlling the filling of the cylinders with the charge of the working mixture.

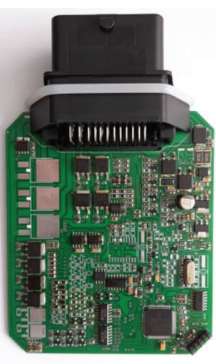

a

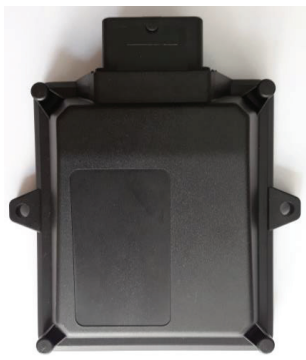

$b$

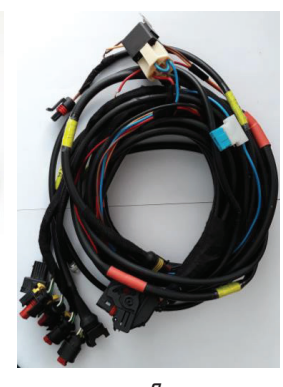

Fig. 2. Multifunctional microprocessor electronic contral unit (ECL) Avenir Gaz 37 «B»: a - Avenir Gaz 37 «B» board assembled; $b$ - ECU appearance; $c$ - wiring harnesses for connecting the control unit with sensors and devices

ECU Avenir Gaz $37 \ll B »$ is built on the platform of a high-performance 16-bit microcontroller PIC24F (Microchip Technology Inc.) with nanoWatt XLP technology, which provides ultra-low power consumption. The device includes advanced power saving features including low voltage mode. The maximum clock frequency is $32 \mathrm{MHz}$. The computing power (performance) of the microcontroller at the operating frequency reaches 16 DMIPS.

The conducted non-motorized tests of the Avenir Gaz 37 «B» ECU confirmed its operability and showed that the computing power (performance) of the ECU with the PIC24F microcontroller allows to control the operation of the gas engine in real time.

Bench tests of the D-240-LPG-«B» model gas engine with the developed electronic microprocessor control system and the Avenir Gaz 37 «B» ECU confirmed the provision of both group and sequential LPG injection.

The operation principles of the developed system of electronic microprocessor control of a transport gas ICE with an Avenir Gaz 37 «» ECU, which provides group injection of LPG, are described in detail in [13]. New in this control system is the presence of electronic communication between the ECU and the Hall sensor of the distributor, which ensures trouble-free operation of the system in the event of a failure of the engine speed sensor.

In turn, the operation principles of the developed system of electronic microprocessor control of transport gas ICE with ECU Avenir Gaz $37 \ll \mathrm{B} »$, which provides sequential injection of LPG, are described in [14]. New in this control system is the ability to implement sequential injection of LPG into the ICE, in the standard configuration of which there is no camshaft position sensor and a special master disk installed on the camshaft. To implement this, the ignition system was modified by making changes to the design of the standard master disk (obturator) of the distributor. The standard master disk (obturator) is modified by increasing 
the length of the arc of the sector of the circumference of the opening of the first cylinder. Thanks to this, the ECU receives a signal from the Hall sensor of the distributor, which determines the moment of the position of the piston in the first cylinder relative to the top dead center.

Tests have shown that the control system performs the following basic and additional functions as:

- precise dosing of the required amount of gas fuel into each ICE cylinder;

- regulation of the amount of starting gas fuel supply depending on the temperature of the engine coolant; - regulation of the ICE rotational speed in idle mode, depending on the coolant temperature;

- limiting the maximum rotational speed of ICE by

forming an external regulatory characteristic and the like.

Bench tests of the D-240-LPG-»B» model gas engine with an electronic microprocessor control system and Avenir Gaz 37 «B ECU have confirmed the efficiency of its operation.

It is known from the information of the World LPG Association (WLPGA) [10] that LPG is the world's most widespread alternative motor fuel for transport. Considering the widespread use of LPG, as well as the fact that it is the cheapest fuel in Ukraine [15], converting diesel engines into gas ICE is an effective way to reduce the operating costs of diesel vehicles.

\section{Conclusions}

The expediency of converting diesel engines of vehicles into gas ICEs with forced ignition for operation on LPG is shown. An electronic microprocessor control system for gas ICEs with spark ignition has been developed. A special multifunctional electronic control unit Avenir Gaz 37 «»» has been developed and manufactured, which, as part of the control system, depending on the software version, is capable of implementing group or sequential LPG injection. It has been proven that converting diesels to gas ICEs is an effective way to reduce the operating costs of diesel vehicles.

\section{References}

1. Genkin, K. I. (1977). Gazovye dvigateli. Moscow: Mashinostroenie, 196.

2. Vansheidta, V. A., Ivanchenko, N. N., Kollerova, L. K. (Eds.) (1977). Dizeli. Leningrad: Mashinostroenie, 480.

3. Zakharchuk, V. I. (2011). Osnovy teorii ta konstruktsii avtomobilnykh doyhuniv. Lutsk: LNTU, 233.

4. Luksho, V. A., Kozlov, A. V., Terenchenko, A. S., Ter-Mkrtichian, J. G., Karpukhinn, K. E. (2015). Technical and Economic Analysis of Vehicles Pollutant Emissions Reduction Technologies.
Biosciences Biotechnology Research Asia, 12 (2), 1867-1872. doi: http://doi.org/10.13005/bbra/1852

5. Mo, H., Huang, Y., Mao, X., Zhuo, B. (2016). Investigations on the Potential of Miller Cycle for Performance Improvement of Gas. Engine Global Journal of Researches in Engineering, 16 (1), 37-46.

6. Abramchuk, F. I., Manoilo, V. M., Dziubenko, A. A. (2011) Eksperimentalnaia ustanovka dlia issledovaniia gazovogo dvigatelia 6GCHN 13/14 s nadduvom i prinuditelnym vosplameneniem. Avtomobilnii transport, 29, 43-51.

7. Manoylo V. M. (2018). Research performance engine car motor 6HCHN 13/14 supercharged and distributed gas supply. Machinery \& Energetics. Journal of Rural Production Research, 9 (2), 143-147.

8. Abramchuk, F. I., Voronkov, A. I., Otchenashko, S. I. (2008) Analiz kamer sgoraniia, ispolzuemykh v sovremennykh vysokooborotnykh avtomobilnykh dizelnykh dvigateliakh. Avtomobilnii transport, 22, 117-122.

9. Kovalov, S. (2020). Designing the shape of the combustion chambers for gas engines converted on the basis of the diesel engines. Eastern-European Journal of Enterprise Technologies, 2 (1 (104)), 23-31. doi: http://doi.org/10.15587/17294061.2020 .198700

10. World LPG Association. About LPG. Available at: https://www. wlpga.org/about-lpg/applications

11. Regulation No. 67 LPG vehicles. Available at: https://www.unece. org/fileadmin/DAM/trans/main/wp29/wp29regs/R067r3e.pdf

12. Kolisni transportni zasoby. Vymohy bezpeky do konstruktsii ta tekhnichnoho stanu kolisnykh transportnykh zasobiv, doyhuny yakykh pratsiuiut na hazovomu motornomu palyvi, ta metody kontroliu: DSTU 7434:2013 (2014). Kyiv: Minekonomrozvytku Ukrainy, 28.

13. Kovalov, S. O., Plys, S. V. (2020). Pat. No. 144229 UA. Systema upravlinnia robotoiu dvyhuna vnutrishnoho zghoriannia iz elektronnym blokom upravlinnia, dlia zabezpechennia hrupovoho vporskuvannia hazovoho palyva. No. u 2020 03041. declareted: 21.05.2020; published: 10.09.2020. Bul. No. 17.

14. Kovalov, S. O. (2020). Pat. No. 144091 UA. Systema upravlinnia robotoiu dvyhuna vnutrishnoho zghoriannia iz elektronnym blokom upravlinnia, dlia zabezpechennia poslidovnoho vporskuvannia hazovoho palyva. No. u 202003826 declareted: 25.06.2020; published: 25.08.2020. Bul. No. 16 .

15. Tsiny na benzyn, DT, haz na zapravkakh Ukrainy. Vse AZS Available at: http://vseazs.com

Kovalov Serhii, PhD, Senior Researcher, Research Laboratory for Fuels Use and the Ecology, State Enterprise «State Road Transport Research Institute»,Kyiv,Ukraine, e-mail: skovalev@insat.org.ua, ORCID: http://orcid.org/0000-0002-3107-530X

Parsadanov Igor, Doctor of Technical Sciences, Professor, Department of Internal Combustion Engines, National Technical University «Kharkiv Polytechnic Institute»,Ukraine, e-mail: parsadanov@kpi.kharkov.ua, ORCID: http://orcid.org/0000-0003-0587-4033

Plis Serhii, Radio engineer, Private Individual Entrepreneur Plis Serhii Vasiliovich, Kremenchug, Ukraine, e-mail: ultrasat@gmail.com 